\title{
AN INVESTIGATION INTO A ROLE FOR MUNICIPAL PLANNERS IN DECISIONS PERTAINING TO THE FUTURE OF SURPLUS SCHOOLS
}

by

\author{
Lauren Michelle Sauve \\ B.Sc.H., Queen's University, 2011 \\ A Major Research Paper \\ presented to Ryerson University \\ in partial fulfillment of the requirements for the degree of \\ Master of Planning \\ in \\ Urban Development
}

Toronto, Ontario, Canada, 2014

(C) Lauren Sauve, 2014 


\section{Author's Declaration}

I hereby declare that I am the sole author of this Major Research Paper. This is a true copy of the Major Research Paper, including any required final revisions, as accepted by my examiners.

I authorize Ryerson University to lend this Major Research Paper to other institutions or individuals for the purpose of scholarly research.

I further authorize Ryerson University to reproduce this Major Research Paper by photocopying or by other means, in total or in part, at the request of other institutions or individuals for the purpose of scholarly research.

I understand that my Major Research Paper may be made electronically available to the public. 


\title{
AN INVESTIGATION INTO A ROLE FOR MUNICIPAL PLANNERS IN DECISIONS PERTAINING TO THE FUTURE OF SURPLUS SCHOOLS
}

\author{
(C) Lauren Sauve, 2014 \\ Master of Planning \\ in \\ Urban Development \\ Ryerson University
}

\begin{abstract}
In addition to facilitating the education of children, school buildings and their surrounding footprint offer a wide range of community benefits. Consequently, when student enrolment falls and these buildings are slated for closure, the public benefits that these facilities provide are lost to the surrounding neighbourhood. Currently in Ontario, the mandate for school boards when closing surplus schools appears to be detached from that of the corresponding municipality. This MRP explores what is preventing these two entities from working together presently, and subsequently hypothesizes the role of a legislated partnership between municipalities and school boards when decisions are being made about the future of these sites. Not only would a more collaborative relationship between municipalities and school boards be beneficial in evaluating the potential for joint or alternative uses for school sites, but it would also afford an opportunity for municipal planners to study the intangible benefits of a school and the impact of closures on Official Plan policy objectives. The potential role for municipal planners in the school closure decision-making process will therefore be central to the findings of this paper.
\end{abstract}

Key Words: surplus schools; Accommodation Review; municipal planners; Ontario 


\section{Acknowledgements}

I would like to thank my supervisor, Ronald Keeble, for his insights into the subject and for his willingness to spend considerable time organizing my thoughts and pointing me in the right direction. His feedback after each one of my drafts was instrumental to the completion of this paper.

I would also like to thank Dr. Joseph Springer, for his thorough review of my work and for his valuable suggestions to improve the paper.

Finally, none of this would have been possible had it not been for my mom, dad, and sisters. Their unwavering love and support have pushed me to never give up on my goals. 


\section{Table of Contents}

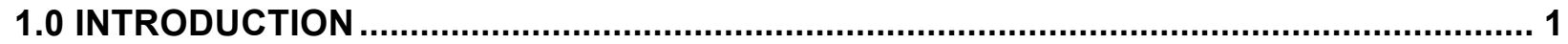

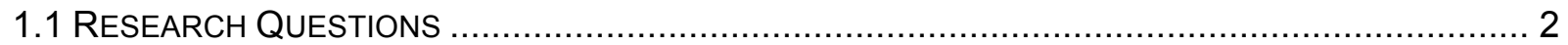

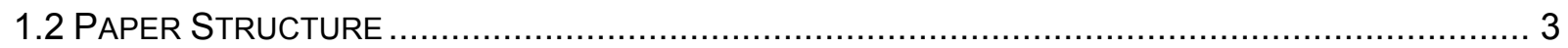

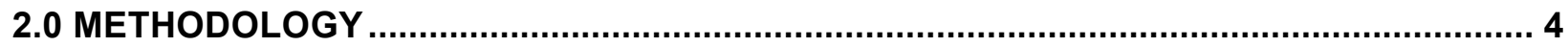

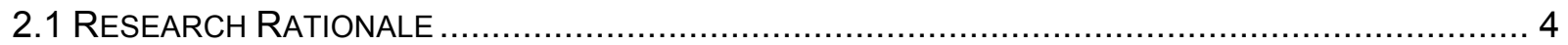

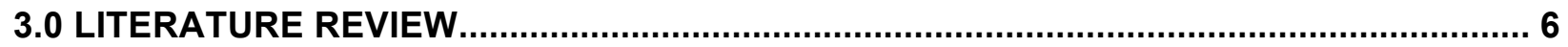

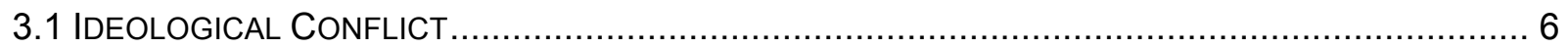

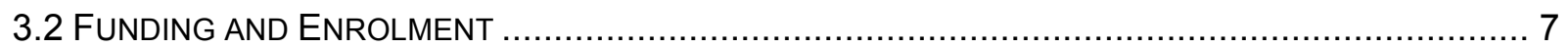

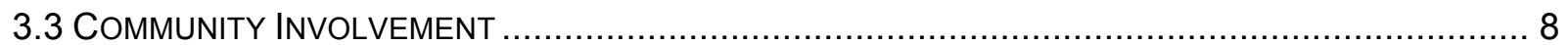

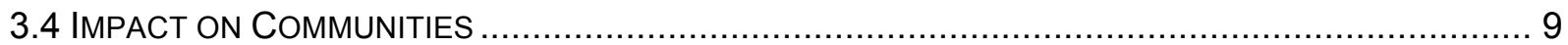

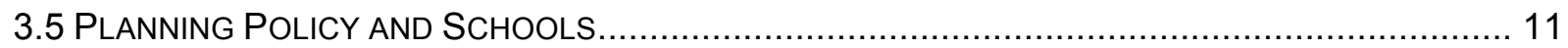

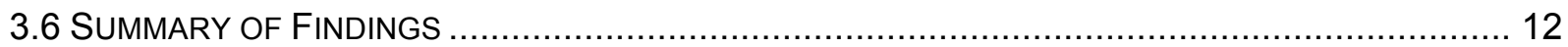

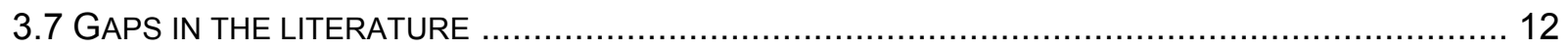

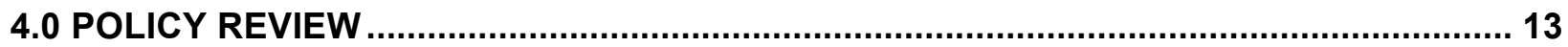

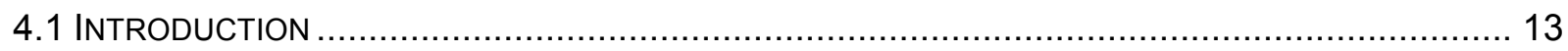

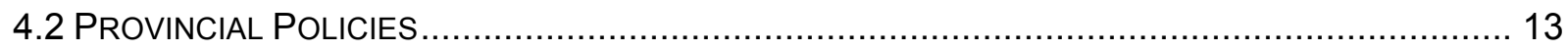

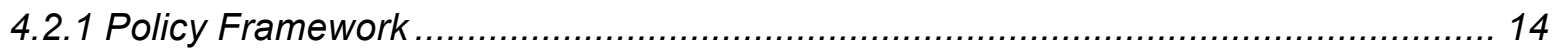

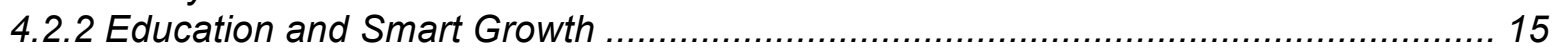

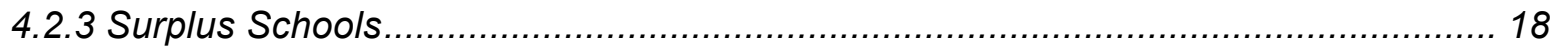

4.3 LOCAL LAND USE AND SCHOOL CLOSURE POLICIES ................................................ 19

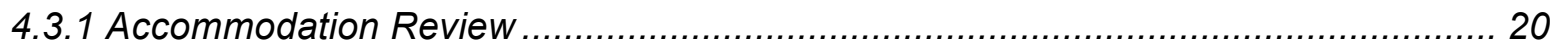

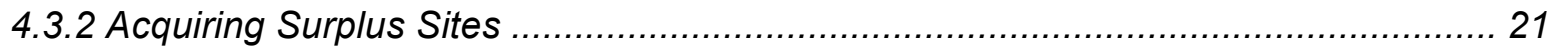

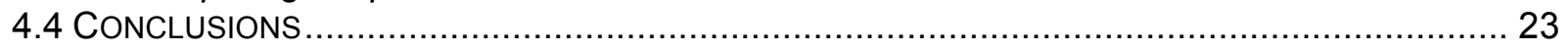

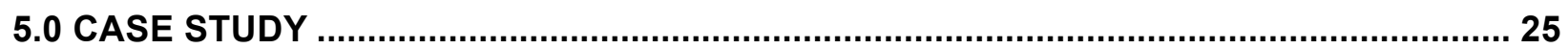

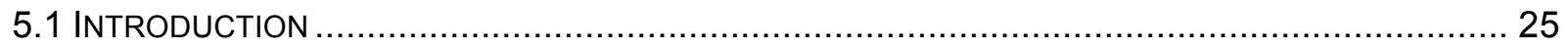

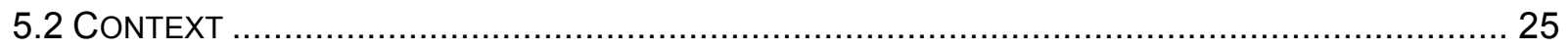

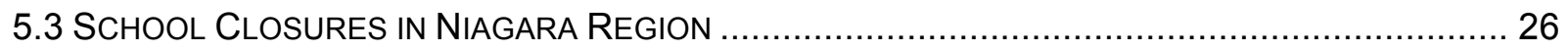

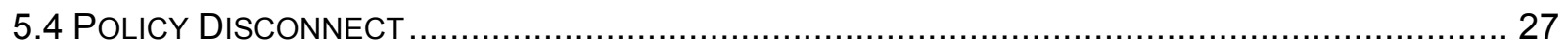

5.5 REGION OF NIAGARA - SMARTER SCHOOLS FOR SMARTER GROWTH ............................. 28

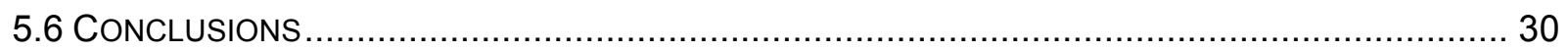

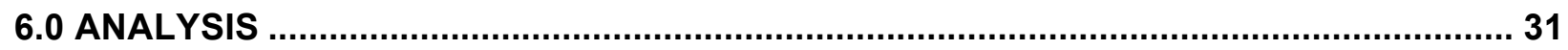

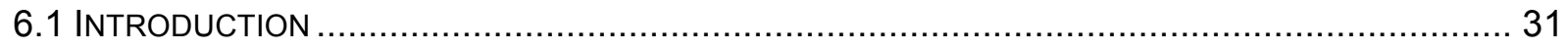

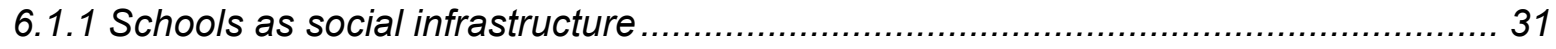

6.2 ROLE FOR MUNICIPAL PLANNERS - SURPLUS SCHOOL DECISION-MAKING ....................... 32

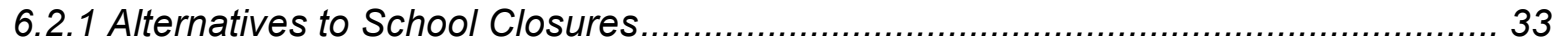

6.2.2 The Full Costs of School Closures ................................................................. 39

6.3 Role For MUNICIPAL PlanNeRS - AcCOMmOdation ReVIEW CONSUltation PROCESS .... 46

6.3.1 Alternative Decision-Making Models ............................................................. 47

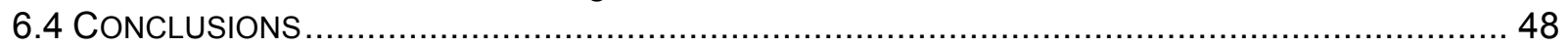

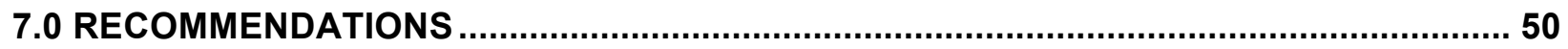

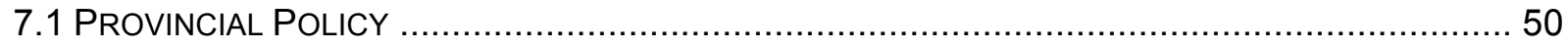

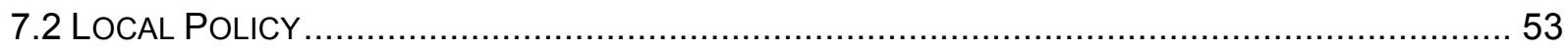

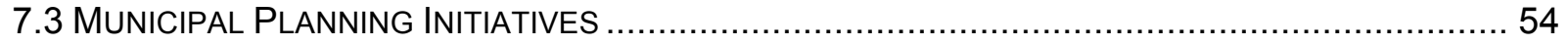

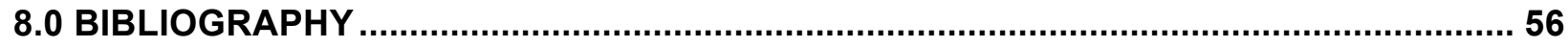




\section{List of Tables}

Table 1 - The objectives of municipal planners in satisfying a municipality's Urban Community Objectives 


\subsection{INTRODUCTION}

Schools are a place of education for children - they are also an important part of the community fabric. School facilities and grounds are integral components of public infrastructure that not only provide students with space to learn and socialize, but that also have the potential to provide entire communities with benefits that extend beyond the time when the school day is over. As interest grows in addressing concerns like the lack of open space, suburban sprawl, and the need to efficiently use public resources, it is critical that the definition of school spaces be extended to include non-school uses and users (Vincent, 2010).

In Ontario, schools are the real property of School Boards. As such, public School Boards are tasked with delivering programs, managing schools, and ensuring student success as per the Ministry of Education Guidelines. Municipalities; however, are responsible for planning sustainable communities through balancing economic, social, and environmental factors. To a municipality then, schools become irreplaceable community assets (Seasons, 2013). Both the buildings and the land upon which these structures stand become important community hubs.

When a school has been slated for closure, a fundamental tension arises between what is best for the school board and what is best for the municipality. While decisions to close schools are most often shaped by fiscal constraints, declining enrollment, infrastructure deficits, and the cyclical nature of neighbourhood demographics; their important connection to the long-term strategic planning initiatives means that these decisions tend to capture the attention of urban planners and municipal officials. Despite this important connection between schools and communities, municipalities have no formal role in the school closure decision-making process. To date, school boards and municipalities exist in parallel professional frameworks. Municipal planners are rarely consulted in the school closure decision-making process, and if they are, it is often only as a professional courtesy (Irwin \& Seasons, 2012). 
For the reasons above, permanent school closures are an emerging topic of discussion in both the planning profession and academia. Presently in Ontario, 60 of 72 School Boards are experiencing enrolment decline (Seasons, 2013). The reality is then, that schools will likely close. Notwithstanding the increasing prevalence of this phenomenon occurring in many communities province-wide, there has been a limited amount of research in this field. The purpose of this paper is therefore to examine the relationship between the factors that inform school closure decisions and the factors used to assess the impact of closure on surrounding communities. The lens through which the research will be carried out labels schools as important pieces of local community infrastructure. Starting with high-level Provincial policies, it seeks to assess whether municipal planning objectives and the provision of community services are considered throughout the process.

\subsection{Research Questions}

The research seeks to satisfy four main objectives: understand the important role of schools in a community, understand how policy at both the Provincial and local level is informing school closure decisions, identify possible alternatives to school closures, and attempt to address what needs to be done from a municipal planning perspective in response to this contentious issue. To meet these objectives, this paper aims to answer the following questions:

- How is provincial policy informing the school closure decision-making process at the local level? Are these policies encouraging coordination between school boards and municipalities?

- Are the implications of closure on the community factored into the decision to close schools? If so, how? If not, why?

- Should municipal planners have a formal role in the school closure decision-making process? What would this role look like? 
- In the case of surplus schools, is there a way that the public benefit can be factored into the decisions about the future of school lands and buildings?

\subsection{Paper Structure}

The paper will be will be composed of seven main chapters. The second chapter expands on the methodology and the limitations of the research. In Chapter three, a literature review is presented to highlight important themes surrounding reasons for school closures, as well as their impact at the community level. In chapter four, a policy and process review is conducted at both provincial and local scales. Chapter five will explore a case study of the Niagara Region through which the on the ground shortcomings of the current policy framework will be illustrated. Chapter six considers a role for municipal planners in the school closure decision-making process. Finally, based on the analysis, Chapter seven provides recommendations for future research and policy development. 


\subsection{METHODOLOGY}

The research was comprised of three significant components. For the purposes of analyzing why formal relationships between municipalities and school boards do not currently exist at the provincial or local level, it was necessary to conduct a review of pertinent policies associated with Accommodation Review, Land-Use Planning, and the Disposal of Surplus School Sites. Next, because of the high level nature of the policy pieces pertaining to surplus schools, an important component of the study was to perform a case study analysis of how these policies play out at the local level. Examining a school board's planning policies and Accommodation Review Guidelines provided information about how a region saw itself doing as well as identified gaps in its process. The decision to use the Niagara Region as a case study built off research done by Andres (2013) that highlighted augmenting tension between municipalities and school boards in this area. Diving deeper into why these issues emerged and what steps are being taken as a result provided a direction for further policy analysis and recommendations. Finally, based on the findings from the policy review and the case study, an analysis was conducted that focused on a role for municipal planners in the school closure decision-making process. In this section, the benefits of a more collaborative decision-making model between municipalities and school boards were the most significant areas of discussion.

\subsection{Research Rationale}

It is anticipated that this research will be valuable to both municipal and school board planners. For municipal planners, the research should allow them to better understand the process behind school closures in city neighbourhoods. The research may also result in municipal planners becoming more in tune with how the process impacts the local community and how it relates to broader issues surrounding city growth patterns. For school board planners and bureaucrats, the study should provide insight into the current gaps in the decision making process as well as how to better represent the needs of the community when making these 
difficult decisions. More importantly, the research will view the school closure decision-making process through the lens of a school as an important piece of community infrastructure. In this view, urban planning policies and objectives will be central to the evaluation of the how decisions are currently being made about surplus schools and what could be done to strengthen this process. 


\subsection{LITERATURE REVIEW}

The implications of school closures have long been a topic of outrage and frustration for the communities affected. Often, these opinions stem from the popular opinion that the agendas for closing schools are detached from that of the affected community (Irwin, 2012). The following section will attempt to summarize the source of these frustrations through presenting the existing literature on the topic.

Recent literature on school closures and their effect on neighbourhoods can be organized into four important themes: Ideological conflict, Funding and Enrolment, Community Involvement, and Community Impact. The literature has also begun to explore the relationship between the fields of Education and Urban Planning.

\subsection{Ideological Conflict}

In late 1997, Premier Harris introduced two pieces of provincial legislation that considerably weakened the way in which communities make decisions about local schools (FreduaKwarteng, 2005). The introduction of Bill 160, The Education Quality Improvement Act (Ontario, 1997a) and Bill 104, The Fewer School Boards Act (Ontario, 1997b), marked the beginning of a transition period that saw the once local decision-making power becoming significantly centralized in the hands of the province, and fiscal implications becoming the dominant measurement of all education decisions (Irwin, 2012). In fact, a fundamental tension was introduced between the two ideological approaches to school closures: one based on the neoliberal principles of efficiency and accountability, and the other based on the symbolic meaning and value of schools to neighbourhoods (Basu, 2007). Witten et al. (2003) emphasizes that the introduction of efficiency-based policies undermines the important role that a school plays in the life of a neighbourhood and a community by failing to take into account the often intangible social and cultural benefits that these buildings provide. 
To this end, questions are raised concerning the potential beneficiaries of school closure decisions. Irwin (2012) claims that school board officials tend to take the neo-liberal position that they "own" the school, and as the owners, it is their duty to operate them in the most efficient and effective manner possible. In this policy context, Witten et al. (2003) argues that education has been recast as an investment in human capital, rather than a public benefit. By contrast, Fredua-Kwarteng's (2005) study maintains that parents and other community members perceive local schools as belonging to them; they see communities as the "real owners" of local schools. Since the introduction of these policies in late 1997, this important tension is most cited as the underlying factor in school closure debates.

\subsection{Funding and Enrolment}

In terms of education funding, the impacts of Bill 160 included the removal of school boards' ability to levy property taxes for education and the imposition of a province-wide per-pupil funding formula (Kitchen, 2002). Whereas school boards used to have the power to set their own property tax rates to fund education in their jurisdictions, Ontario's Ministry of Education has now assumed this responsibility (Canadian Federation of Municipalities, 2005).

Consequently, school boards no longer have control over how much revenue they receive on an annual basis. Instead, that revenue is distributed to local school boards using a province-wide funding formula that provides funds for education programming on a per-student basis and funding for school operations on a dollar per square foot basis (Mackenzie, 2007).

In a recent review of the impact of the funding formula on a school board's capital program, People for Education (2009) suggest that the funding formula continues to be the most significant factor in school closures. Where policymakers have argued that closure should be viewed as a last resort (Irwin, 2012), School Boards appear to have their hands tied by a funding formula that is best suited for the policies of economic efficiency rather than the provision of goods and comprehensive student success (Fredua-Kwarteng, 2005; People for 
Education, 2009; Andres, 2013).

The major criticism of the funding formula is that it is too tightly bound to enrolment (People for Education, 2009). In fact, research shows that the funding formula's strong reliance on student enrolment is causing school boards to establish larger schools, often at the expense of smaller, inner city schools or rural schools, in order to provide an appropriate breadth of programs (Basu, 2013; Vincent, 2006; Andres, 2013).

Another criticism of the funding formula is that it has not been properly updated since its implementation (Mackenzie, 2007). When the formula was developed in 1997, it was based on average school sizes at the time (People for Education, 2009). Since 1997; however, the average enrolment in Ontario's elementary schools has declined by $15 \%$. By contrast, the perpupil allocations for staff and for square footage have not changed (Mackenzie, 2007). Additionally, schools offering alternative programs like child care centres, after-school activities, or settlement services are deeply affected as this space usage goes unfunded (Basu, 2007).

\subsection{Community Involvement}

In 2006, the Ministry of Education introduced a process known as Pupil Accommodation Review that was to be undertaken by local school boards whenever decisions are being made to close or consolidate schools (Ontario, 2006). Appointed by the School Board, an Accommodation Review Committee made up of parents, educators, board officials, and community members provides recommendations that inform final decisions made by the Board of Trustees. To help guide the process, the Province introduced the Pupil Accommodation Review Guidelines that provide school boards with criteria that must be used to determine the value of a school in four key areas: to the community, to the students, to the board, and to the local economy. In 2009, the Guidelines were updated to include mandatory public meetings and community consultations that would "ensure that school closure decisions are made with the full involvement of an informed local community" (Ontario, 2009). 
Critics of school board practices; however, have advanced the position that in terms of school closure, procedures may create the appearance of community consultation when in fact; the process acts as a democratic formality (Doern \&Prince, 1989; Fredua-Kwarteng, 2005; Irwin, 2012; Irwin \& Seasons, 2012). Although the language of the Accommodation Review Guidelines endorse a participatory, community focused process in the deliberation of a school's continued viability; research shows that they have been largely unsuccessful. For example, the regulations do not specify what types of involvement school boards should allow a community in closure decisions and whether the community's involvement should be truly joint or collaborative (Fredua-Kwarteng, 2005; Hampton, 2009). Similarly, Irwin (2012) argues that while the current guidelines (Ontario, 2009) cite the need to consult the community in the decision-making process, it avoids specifying to what degree, the intensity, and the depth of that consultation. It also neglects to address whether the local school board is actually obligated to consider the community's input once it is gathered.

\subsection{Impact on Communities}

The impact of school closures on the surrounding community is an area that is limited in study. Those who have attempted to study the impact of school closures have been largely unsuccessful because of the difficulty associated with quantifying data that is un-quantifiable in a traditional sense (Seasons, 2013). Notwithstanding this challenge, many studies have been able to show that schools in most rural and urban communities are much more than a place where education occurs. The underlying theme present in all these studies has been the loss of community that results from the closure of schools (Basu, 2007). The following section will explore the impact of school closures on communities at three different scales - at a personal, neighbourhood, and community level.

Irwin's (2012) study on the impacts of Ontario school closures is one of the few Canadian studies that examine how closures affect individual community members. His research found 
that community members are impacted by school closures on a personal level. Three of the most pervasive outcomes of his study were a sense of participants' personal connectedness with the school, profound emotional grieving at its loss, and the school having an iconic place in the community. Even those community individuals who do not currently have, nor ever had, children in school tended to hold this view (Witten et al., 2001).

A study by Bushrod (1999) grapples with the impacts of school closures at the neighbourhood level. It found that residents feel as though there are fewer opportunities to socialize in neighbourhoods that have experienced school closures. Fredua-Kwarteng's (2005) study considered the effect of school closures on overall neighbourhood vitality. She concluded that some of the negative effects of a school closure included loss of a central focus for the community pride and solidarity, a perceived decrease in property values, a reluctance of child bearing potential families to settle in the area, and a disruption of students social contact and academic learning. Particularly in low-income neighbourhoods or small communities, the impact of a school closure changes the fabric of the neighbourhood.

Kearns, Lewis, McCreanor, and Witten's (2009) study of school closures in Invercargill, New Zealand draws "attention to the educational effects of the loss of local knowledge in teaching and learning, the effects of increased travel on daily lives, and the economic effects of stripping yet another service from a disadvantaged community". This study presents schools as an important part of the community's fabric. Irwin \& Seasons (2012) add that schools are a key component to building a community's social capital. Finally, school lands and buildings support community activities through acting as important meeting places for community members and contributing to an overall sense of place (Witten et al., 2003; Kearns et al., 2009; Irwin \& Seasons, 2012). 


\subsection{Planning Policy and Schools}

Recently, a growing body of literature has emerged surrounding the need for a better relationship between the fields of urban planning and education planning. A 2013 study focusing on the Accommodation Review Process in Ontario illustrated the diverging mandates of School Boards and Municipalities (Seasons, 2013). Where school board planners attest that the fate of school closures should be decided solely by Board Staff, municipal planners in the study saw the process as counterproductive to the best possible outcome for a community (Andres, 2013). Anders (2013) also pointed to an example in Niagara Region where the growing tensions between municipalities and school boards surrounding these issues have led to recommendations being approved by local council that encourage these two groups to work together. Municipal governments in Ontario also do not have the power to challenge school board decisions, which Fredua-Kwarteng (2005) argues is a weakness in the system. On the whole, planners argue that the all-inclusive analysis required for community planning does not factor into Accommodation Review (Irwin \& Season, 2012; Vincent, 2006).

From a policy perspective, school closure is a major concern for municipal governments whose urban planning objectives for inner cries (e.g. intensified forms of development, downtown revitalization, and the creation of complete communities) are undermined when schools close (Ontario, 2012a; Filion \& Bunting, 2010). Vincent (2006) goes so far as to suggest that this is because school boards and municipalities operate in different silos. He shows that this divide is evident in local practice, research, professional degree programs, and most levels of policy making.

Finally, in a paper that appears to be the first of its kind, Vincent (2010) focuses on the joint use of school buildings. The research investigates the politically and logistically difficult practice of forming local partnerships between California school districts and other local entities to 
mutually invest in and share the use of school facilities (Vincent, 2010). The research concludes that in order to formalize these partnerships, formal agreements are likely required.

\subsection{Summary of Findings}

After reviewing the literature on school closures, three important conclusions applicable to Ontario can be drawn. First, a result of the neo-liberal principles upon which it is built, the current education funding formula fails to address the intangible elements that schools add to a community. Given that funding and enrolment are cited as the two most dominant reasons for school closure, education policies are failing to recognize the important role that schools play in neighbourhood vitality. Second, closely tied to the funding formula, policies pertaining to the Accommodation Review process appear to purposely ignore the impact that school closures have on affected communities. Lastly, the need for a more formal recognition of the important roles that schools play in creating complete communities is beginning to emerge.

\subsection{Gaps in the literature}

Though studies have portrayed the need for better collaboration between municipal governments and school boards when decisions are being made about the future of surplus schools, the question of why these two public entities do not work together presently has not been well studied. Additionally, studies have failed to suggest what policy changes would be required to formalize this relationship. They have also been unable to show how a formal role for municipal planners in the school closure decision-making process would play out at the local level. Finally, Vincent's 2010 study examines criteria for joint use of American school buildings, but a similar study has not been performed in the Canadian context. 


\subsection{POLICY REVIEW}

\subsection{Introduction}

Policies shape local processes for both municipalities and local school boards. Examining and analyzing pertinent municipal land use and school closure decision-making policy is therefore the most critical component of understanding why these planning entities do not work together when making decisions about surplus schools.

The following section will examine in detail why perverse provincial and local policies and practices are discouraging municipalities and school boards from working together when discussing the future of surplus schools. For the purposes of this investigation, "policy" will refer to all legislation, goals, objectives, and other relevant guiding principles (Andres, 2013). Policy by definition is the written prescription for a problem or a description of intent for an organization to follow in the decision-making process (Pal, 2006; Andres, 2013). The term "process" will then be used as the basis for the evaluation at the local level. Effectively, process refers to the follow through or actions guided by policy (Irwin, 2012). The analysis performed in this section will be used as the basis for a case study that will follow in Chapter four in which the 'on the ground' results of the provincial-local policy gaps will be illustrated.

\subsection{Provincial Policies}

Both public school boards and municipalities are creatures of the Province. Each of these local governing bodies receives legislative and policy objectives that outline their roles and responsibilities. As such, provincial policies not only give these governing bodies their power, but they also define to what extent they can exert that power. In essence, the roles and responsibilities of both school boards and municipalities are shaped and informed by high-level provincial policies. It is important to ask then, when it comes to the future of surplus schools, why the same provincial government is creating and implementing what appear to be 
uncoordinated policies for school boards and municipalities.

At the provincial level, three main policy issues can be used to explain the lack of collaborative decision-making models between School Boards and municipal planning departments. The first has to do with the ideological framework within which policies for urban and education planning are shaped. The second point of contention concerns the policies themselves, and the fact that there is currently no institutional framework that creates space for the provincial Ministries for Education, Municipal Affaires and Housing, and Infrastructure to plan together (Vincent, 2006). This sectoral fragmentation of policy-making jurisdictions makes school facility planning logistically difficult and politically contentious. The final policy objectives that will be discussed are those of Ontario's Regulation 444/98, which deals with the sale of surplus school sites. Like the decision-making process itself, this policy fails to recognize the value of schools to the overall community.

\subsubsection{Policy Framework}

The diverging ideologies behind policy creation for education and urban planning lend themselves to two very different mandates for municipal planning departments and local school boards. On their part, urban planners are concerned with place and place making. Since the 1960s, urban planners have understood that complicated and interconnected societal, environmental and economic issues could not be satisfactorily addressed by a wholly "rational" decision-making approach (Hodge \& Gordon, 2008; Irwin \& Seasons, 2012). As such, they steadily moved away from this method and shifted toward decision-making models that have a stronger focus on collaboration and consensus building (Irwin \& Seasons, 2012). When decisions are made about other types of public infrastructure projects, many stakeholders are encouraged to work together.

The Ministry of Education; however, continues to develop policies that are based on specific measures of efficiency. As such, they have effectively tied the hands of school boards 
when they are making decisions about local schools (Basu, 2004). By focusing so heavily on efficiency and education programming, education in Ontario follows a very one-dimensional policy direction. In reference to the Accommodation Review policies that assert community involvement, Keevers et al. (2008) contend that even when an organization is committed to pursuing the principles of social justice and community engagement in their policy deliberations, the influence of the "business case" is so prevalent that it negates all other positions (Irwin, 2012).

As will be illustrated further by the Niagara Region Case study, the Provincial Pupil Accommodation Review Guidelines appear to place more weight on the fiscal performance of a school than on its role in the community. Ultimately, the reliance of education funding on a perpupil formula places far too much pressure on enrolment. Schools must cope with cyclical changes in student enrolment, making it difficult to afford an adequate supply of facilities in the context of increases and declines in enrolment (Basu, 2004). Particularly in the present context, municipalities are under intense pressure from senior government in Ontario to rationalize their services and resources (Irwin \& Seasons, 2012; Kearns et al. 2009). In June 2013, the Ministry of Education reported that $30 \%$ of pupil spaces in Ontario are surplus. The Ministry has also stated that since surplus space has a direct impact on the allocation of operational and capital funding for boards that is based on student enrolment, "the Ministry of Education will not provide additional funding for new schools or major additions if there are surplus spaces in the Board" (People for Education, 2009). What this means at the local level is that there is tremendous pressure to close schools in some areas in order to provide new schools in areas experiencing growth. As such, School Boards are challenged by the need to cut costs and not give up scarce sites for the future (Irwin \& Seasons, 2012). 


\subsubsection{Education and Smart Growth}

A major flaw in school closure policy stems from the fact that the Provincial Ministries responsible for education, infrastructure, and urban planning operate in different organizational silos (Vincent, 2006; Irwin \& Seasons, 2012). In fact, the Provincial Policy Statement of Municipal Affairs and Housing, issued under Section 3 of the Planning Act, does not have specific Official Plan guidelines for Provincially funded school buildings (Smarter Niagara Steering Community, 2011). On the other hand, Ontario school boards are autonomous agencies created by the province's Education Act (Rasanu, 2012). What this means is that school boards operate in different provincial regulatory environments than do local municipalities. While boards and municipalities may cooperate to encourage community use of school facilities, they often make decisions independently because of their different responsibilities. This significant weakness of the Provincial Policy Statement and the Education Act affords the Ministry of Education, and consequently local School Boards, relative freedom in school site selection and significant leverage over municipalities when sites are identified for closure (Smarter Niagara Steering Community, 2011). While schools are a critical piece of infrastructure in the formation and resiliency of neighbourhoods, the municipal representatives who are responsible for building these communities have no formal say in the decision-making process that leads to their closure (Andres, 2013).

Additionally, the study of school population decline and decision-making related to school closure is conducted only by school boards, with no legislative requirement to adhere to the urban planning needs of the community in which these schools are located. There is an important tension here: school boards deliver academic programs, hire staff, and plan and manage school buildings and land (Basu, 2004); they are not responsible for community stability or other municipal government urban planning goals. School boards are encouraged but they are not obligated to integrate their facility planning objectives with those of municipal government. Although there are positive examples of collaborative relationships that exist 
between municipal planners and school board planners, these relationships are often the exception, rather than the rule By operating in isolation from municipalities, government funded school boards have the authority to make development decisions or abandon buildings without reference to the needs of their host communities (Smarter Niagara Steering Committee, 2011).

On the other hand, a main focus of the Ministry of Infrastructure is to push Smart Growth design principles in urban areas. The most recent example of this was the province's introduction of the Growth Plan for the Greater Golden Horseshoe (Ontario, 2006). The main objectives of this plan are to revitalize downtowns, curb urban sprawl, and intensify built up urban areas. In terms of school closures then, Smart Growth principles would require that these decisions be multi-faceted and take into consideration their impact on a municipality's ability to shape its communities in a manner that supports positive neighbourhood development (Smarter Niagara Steering Committee, 2011).

Furthermore, the provincial funding formula for education is constructed in a way that appears to create a bias towards certain types of school development (Andres, 2013). A funding formula that funds education programming and operations based on a per-student funding formula creates perverse subsidies towards larger 'mega schools', while the future of smaller schools are threatened (Basu, 2007). The major problem here is that these smaller schools are often located in neighbourhoods that are experiencing periods of student population decline (Vincent, 2006). In this way, Ontario's funding formula works in complete contrast to some of the funding strategies employed in the United States. In some states, State legislation actually favours the renovation of older schools, rather than the construction of new ones (Beaumont \& Pianca, 2002). With smart growth principles in mind, grants are given to keep existing schools open. For example, the Maryland Public School Construction program directs capital improvements to schools located in areas where new development is sanctioned by the state (Council of Educational Facility Planners International, 2004). From 1997 to 2001, the state allocated more than $\$ 1$ billion to support 1,700 public school construction projects of which 95 
percent of the projects supported capital improvements for existing schools (Maryland Public School Construction program, n.d.). Ontario, on the other hand, has yet to integrate school closures and the development of new schools with Smart Growth principles of mixed-use, walkability, revitalization, and intensification (Vincent, 2006). This obvious disconnect in provincial policy illustrates the need to overcome the discrete silos of decision-making where educational administrative policy operates in near complete isolation from the needs of municipal governments (Smarter Niagara Steering Committee, 2011).

\subsubsection{Surplus Schools}

In terms of dealing with surplus schools, Ontario has established Regulation 444/98 Disposition of Surplus Real Property of the Education Act that concerns the disposal of surplus properties once a School Board closes a school. The regulation specifies the timelines for the circulation notice of available properties, the period of time within which offers must be made (90 days) and how offers should be evaluated (Rasanu, 2012). The school board must first issue a surplus declaration circulation notice to ten preferred public agencies, namely the other school boards and educational and government institutions, to determine whether or not there is interest in acquiring and/or leasing a surplus property. Should multiple offers be received, Boards must evaluate them in accordance with the prescribed priority sequence (Rasanu, 2012) As a result, acquisition rights are first given to local school boards followed by other educational institutions. Municipalities are thus ranked low on this list of preferred agencies. Another concern for municipalities is that, even when they are interested in acquiring the property, there is often not an adequate amount of time for appropriate studies to be completed and funds to be secured before the 90 days have elapsed (Rasanu, 2012). 


\subsection{Local Land Use and School Closure Policies}

Largely the result of the provincial policy disconnect described above, school boards and municipalities also have no formal relationship at the local level. In many ways the Ministry of Education should be held accountable for the decision-making processes carried out at the school board level (Irwin \& Seasons, 2012). That being said, although it is important to recognize that both municipalities and school boards operate in compliance with provincial government legislation, policies and guidelines, very little effort has been made at the local level to remedy this institutional gap.

Provincial legislation aside, local municipalities have failed to adequately address the importance of schools in community neighbourhoods. Municipal planners have largely ignored these decisions, even when, as Orfield (2002) shows, the location and quality of schools has a multitude of impacts on our urban areas (Vincent, 2006). Instead, school closure decisions are made solely by school boards with funding shortfalls most often cited as the stimulus for accommodation review processes (Irwin, 2012; Basu, 2004a; Fredua-Kwarteng, 2005).

School boards also appear to abuse the fact that the province has created a set of guidelines for Pupil Accommodation Reviews rather than a strictly mandated process (Andres, 2013). By having to adhere only to a set of guidelines, as long as they meet the minimum criteria during their process of valuing a school in the community context, this decision cannot be challenged by municipal or provincial governments (Fredua-Kwarteng, 2005).

Finally, because School Boards are the sole owners of schools, policies pertaining to the sale of surplus school sites have been developed in isolation from policies relating to the sale of other municipal buildings. As such, unlike municipally owned buildings, school boards do not require that a planning study be performed prior to the sale of school lands (Rasanu, 2012). When one considers their extensive history of being community hubs and neighbourhood 
gathering places; however, it is worth questioning then, why these buildings seem to be distinguished from other public building when they are threatened with closure.

\subsubsection{Accommodation Review}

The current Accommodation Review policy requires that four important factors must be determined as part of the school valuation process for a school slated for closure. The four valuation factors include the school's Value to the Student, Value to the School Board, Value to the Economy, and Value to the Local Community. Likely a direct result of an inadequate funding formula and a lack of firm policy direction, three of the four value factors discussed above appear to heavily favour the measurement of the material benefits of a school. When evaluating the criteria used to explore the value of a school to the student, school board, and the economy, many of them ultimately relate back to enrolment numbers, range of programs offered, and size and condition of the buildings themselves. Through this process, other programs and services these buildings frequently provide for the surrounding community seem to be devalued because they do not have tangible, cost saving benefits (Andres, 2013). By failing to address these intangible benefits that schools obviously provide, local Accommodation Review processes fail to integrate the human component of the equation (Vincent, 2006). For example, as part of the valuation process of a school to the local economy, school boards are not required to evaluate the financial implications of closure on issues such as the provision of transportation, operating costs of the receiving school, and what to do with closed school buildings (People for Education, 2009).

Furthermore, the criteria that are used to measure the value of a school to the community do not appear comprehensive enough to encompass the intangible benefits that schools provide. For example, there is no formula capable of quantifying social capital, community involvement in the school, or the value of the school to the surrounding community in terms of providing recreation/ green space (Fredua-Kwateng, 2005). There is also no requirement of 
school boards to reconcile with local municipalities or other stakeholders on potential alternative or shared use for school facilities as part of the school closure decision-making process. The fact that municipalities have no opportunity for appeal when decisions are being made about the future of surplus schools, only further discourages collaboration between the two entities (Irwin, 2012). As a result, in terms of measuring the value of a school to the community, it appears that school boards lack both the expertise and the collaborative solution culture that might be found in a forward-thinking municipal planning department (Andres, 2013).

Finally, the fact that school boards are given exclusive authority over the decision to close schools not only discourages collaboration with local planning departments but also devalues the notion of accountability. Even with community consultation being implemented as a key component of the Accommodation Review Process (Ontario, 2009), school board Accommodation Review Committee processes in Ontario do not appear to be fully participatory and are rarely partnership based or collaborative in nature (Irwin \&Seasons, 2012; Kearns et al., 2009; Doern \& Prince, 1989). In addition, once formalized by a school board, no one can challenge a school board decision unless it can be demonstrated that the board's accommodation review policies were not followed (Fredua-Kwarteng, 2005). This suggests that school board policies and accommodation review processes are at odds with community expectations of inclusiveness, fairness and transparency in public sector agencies (Basu, 2007).

\subsubsection{Acquiring Surplus Sites}

Where a municipality's role in the school closure decision-making process is limited by high-level Education policies, they do have an opportunity to ensure that schools remain in public ownership for continuing neighbourhood use. Unfortunately, though many municipalities have both Official Plan and real-estate management policies that highlight the importance of maintaining public use of surplus school lands, most Ontario municipalities to date lack the policy frameworks necessary to actually acquire these surplus sites for municipal use. 
As will be explained further by the Niagara Region case study, Official Plan policies generally recognize the need to protect school facilities and lands, even if they are not being owned and operated by school boards (Rasanu, 2012). For example, the City of Toronto Official Plan states that:

Keeping surplus schools for community service purposes will be pursued where the need for such facilities has been identified as a priority. Where this is not feasible, alternative uses of closed schools must be compatible with the surrounding neighbourhood and should provide City residents with continued access to school playgrounds and playing fields (City of Toronto, 2010).

In conjunction with these Official Plan policies, cities have also developed strategies through which Regulation 444/98 is implemented at the local level. For example, the City of Hamilton adopted a citywide Real Estate Portfolio Management Strategy in 2004 to guide the management of municipal property owned, leased, sold and acquired (Rasanu, 2012). Though these are positive policy examples of the importance that municipalities place on their schools, municipalities continue to purchase surplus schools on a very ad-hoc basis.

Presently in Ontario, the Cities of Toronto and Burlington are unique in being the only Ontario municipalities with a surplus school acquisition framework that includes a set of corporate acquisition criteria (Rasanu, 2012). The rationale for this process is in direct response to the rigid provincially mandated disposition process that school boards must follow. In fact, City of Toronto staff felt that Regulation 4444 /98 “impedes integrated strategic planning, partnership development and collaborative efforts to retain school board lands as vital public assets. It also undermines the objectives of the Official Plan, local service delivery and placebased planning" (City of Toronto, 2010). Toronto's Acquisition Policy therefore employs a threestep approach that ultimately aims to compare divisional acquisition needs with the ability of surplus school sites to meet these needs (Rasanu, 2012). For this, corporate acquisition priorities were developed in order to rate the viability of sites as childcare centers, parks, forestry and recreation services, affordable housing, or community hubs, as well as to identify 
whether the property is consistent with other goals, objectives or policies of the City Official Plan. Finally, this criterion is meant to evaluate whether partnership opportunities are available. Although this type of policy objective is certainly a step in the right direction, the City of Toronto's policy is not as comprehensive as it first appears. Although presented as a corporate policy that can facilitate the acquisition of school properties to further municipal objectives in an equitable manner, it does no more to encourage actual collaboration between school board and municipalities.

\subsection{Conclusions}

The policy review performed above has illustrated why there is very little collaboration between School Boards and municipalities when making decisions about future schools. From the analysis, two important themes have emerged. First, Provincial Ministries working in isolation from one another has resulted in land use and education policies that are contradictory to one another. Provincial polices for education have not only constrained School Boards in terms of funding, but literature on the subject suggests that the lack of coordination between provincial ministries is resulting in policy objectives that are in contention with provincial policies for Smart Growth and urban revitalization. Secondly, although there are issues to address at the provincial level, problems also exist at the local level, and as such fall under the jurisdiction of school boards and municipalities. Even with Accommodation Review Guidelines requiring that the value of the school to the community be considered in the school closure decision-making process, this process does not seek the input of municipal planning staff, nor is it necessary to undertake a formal planning study before a school is closed. As a result, local Accommodation Review policies do not appear to adequately allow for all economic and community impacts of closing a school to be identified. If social capital and planning goals are critical components of successful city building initiatives, then the process of school closures must take into account the all-inclusive impacts on local neighbourhoods (Andres, 2013). Finally, the lack of initiative 
shown by most Ontario municipalities in creating policies for the sharing, alternate use, or purchasing of surplus school sites further explains why there is no formal planning pro-forma as part of the school closure decision-making process. 


\subsection{CASE STUDY}

\subsection{Introduction}

The following section will serve two important purposes. The first will be to show a specific municipal example of how provincial, local, and education polices play out at the community level. The second purpose of this specific case study will be to show how the Niagara Region has taken proactive steps towards necessitating collaboration between School Boards and municipalities when decisions are being made surrounding surplus schools and use these steps as the basis for further analysis.

\subsection{Context}

The Niagara Region is located in southern Ontario between Lake Ontario and Lake Erie. The Region is at one end of the band of urban development around the western end of Lake Ontario (Niagara Region, 2011). The Queen Elizabeth Way and other provincial highways place most of the Region within ninety minutes' travel time of Toronto. Made up of 12 area municipalities, the Region is home to just over 427,000 residents. Individual municipalities in the region have varying populations, with St. Catharines being the largest municipality with about 131,400 residents in 2011 (Statistics Canada, 2012)

Its location on the Niagara Escapement and its proximity to the City of Toronto has resulted in Niagara being one of many regional municipalities that must comply with the policies outlined in the Growth Plan for the Greater Golden Horseshoe (2006). The Growth Plan has forecast that the population of the Niagara Region will expand from 442,000 in 2011 to 511,000 in 2031 (Niagara Region, 2009). As such, the Region is required to direct at least $40 \%$ of future growth to built-up urban areas (Ontario, 2006). What this means for the Region then, is that they will be expected to build compact, mixed use, transit supportive, pedestrian friendly communities in existing built-up urban areas. 
In an effort to manage the projected regional growth, the Region has devised a framework for developing complete communities all across Niagara (Niagara Region, 2009). This framework formed the basis for growth related policies that are now present in the Region's Official Plan. The main focus of these policies is to ensure compact development, promote the revitalization of downtowns, maximize the use of existing infrastructure, and promote mixed-use development wherever possible (Niagara Region, 2009).

\subsection{School Closures in Niagara Region}

The District School Board of Niagara is responsible for the education of almost 40,000 students within the Niagara Region (Macoomb, 2012). Not unlike other school boards in Ontario, the Region is currently dealing with issues surrounding declining enrolment and increased strain on school budgets for both programming and operations (Smarter Niagara Steering Committee, 2011). Although the Region is experiencing an increase in new houses, the occupancy of these houses is not necessarily families that are in their childbearing years. Additionally, even with the new smart growth regulations being imposed by the Growth Plan, the distribution of these houses continues to shift outward from the Region's city centers. In fact, the combination of low birth rates and shifting migration patterns has resulted in a significant change in the demographic structure of the school-aged population (District School Board of Niagara, 2013). Finally, the fluctuation in value of the Canadian dollar and its negative impact on the manufacturing sector, rising oil and energy prices, and new border crossing rules impacting trade and tourism employment, are all contributing to limited employment opportunities for Niagara residents. Since families are more apt to locate where they can find employment, the fate of many Niagara Region schools is currently hanging in the balance (District School Board of Niagara, 2013). The cumulative impact of these changes in both the demographic and economic fabric of the region has resulted in a decline of elementary school enrolment of approximately $19 \%$ between 2003 and 2012. Furthermore, the fact that this trend is expected to 
carry on well into the future will likely further increase the strain being put on the region's school boards. By 2022, the Board will have a little more than 7,000 surplus elementary spaces, which is the equivalent of approximately 17 - 400 pupil place schools (District School Board of Niagara, 2013).

As such, low enrolment levels at certain schools have prompted the DSBN to undertake a series of Accommodation Reviews to evaluate whether a permanent school closure is required (Smarter Niagara Steering Committee, 2011). From the Board's perspective, these accommodation reviews are necessary to ensure efficient use of space as enrolment changes (Macoomb, 2012).

\subsection{Policy Disconnect}

Though not entirely unique to the Niagara Region, the cumulative impact of the newly implemented growth and land use requirements and the declining enrolment numbers in area schools is resulting in tremendous strain on the region's development. On their part, the Region is stressing that two of its most important objectives are to maximize the use of existing infrastructure to support growth in a compact and efficient manner, and to promote collaboration and cooperation among governments, institutions, and residents (Niagara Region, 2009). For School Boards, demographic trends are forcing the Board to reassess the viability of their schools. As such, their evaluation criteria used to rate each school's viability include factors like: adequacy of the facility for community use; range of program offerings that serve both students and community members; school grounds as green space and/or available for community and recreational use; school as a partner in local community initiatives; and provision before and after school child care programs and Early Years Centres. 
A closer evaluation of these two policy documents reveals that the language of the policy is more suggestive than authoritative. For example, the Official Plan states that:

With recognizing the cyclical nature of school enrolment, the Region encourages the school boards to protect sites for schools as key components in the achievement of complete communities. The Region further encourages consideration of co-location opportunities with complementary community services and shared use of school facilities for public recreation purposes (Niagara Region, 2009).

The use of the words 'should' and 'encourages', allows both school boards and municipalities to interpret these policies as suggestions only and choose inaction over action. Additionally, while the Plan identifies that smaller scale community service facilities are an integral component to liveable, active transportation friendly neighbourhoods and encourages the integration of smaller scale community facilities within neighbourhoods, there is no prescriptive mandate to protect them.

Taken with the conclusions from the policy analysis above, the end result is this: Although each well intended, the current Official Plan for the Region of Niagara, and the Pupil Accommodation Review process are failing to encourage collaboration between municipalities and school boards. In Niagara, not only is this tension creating outcry from community members, but this policy disconnect has recently attracted political attention. In fact, the frustration with the dichotomy between School Board and Municipal Planning objectives eventually boiled over and resulted in a resolution being sent to the Council of Niagara Region.

\subsection{Region of Niagara - Smarter Schools for Smarter Growth}

In the fall of 2009, the Smarter Niagara Steering Committee (SNSC) procured a consultant known as the Working Group to investigate issues and practices related to school closures in the Niagara Region. The central concern they were tasked with investigating was the impact of school closures and new school construction on the success of Provincial and Municipal urban development policies and in particular, the implications for fostering vibrant walk-able neighbourhoods (Smarter Niagara Steering Committee, 2011). Using case studies of recent 
school closures in the area, the Group provided an analysis of the Pupil Accommodation Review process in the Region. Through their analysis, the diverging mandates of school boards and municipalities when it comes to the importance of schools in neighbourhood vitality became clear. Where Official Plan policies stress the objective to build compact, vibrant, sustainable, integrated and complete communities (Niagara Region, 2011); in the three different Accommodation Review processes studied, no mention was made related to the impact of school closure on the neighbourhood, walkability to school, and the potential health and fitness implication of bus travel (Smarter Niagara Steering Committee, 2011). Additionally, through neglecting to evaluate the impact of playground space and the footprint of the school grounds as key factors in the determination of the viability of the school, potential alternative uses to the neighbourhood, or potential land for redevelopment, the obvious need for collaboration with local municipal planning departments was avoided.

In November 2011, the results of this report were presented to Niagara Region's Integrated Community Planning Committee at which time they received a Motion for Approval. The recommendations of this report were centered on creating better coordination between school board and municipal planning objectives. The report called for updates to the Provincial Policy Statement, provincial development policies, and a joint task force with an agreed upon framework for working together to ensure that the interests of both urban planning education are met (Smarter Niagara Steering Committee, 2011). Though each of these three recommendations is valuable and in effect, critical if change is to occur, the last of these recommendations is particularly noteworthy.

In response to the document, with Accommodation Reviews underway at the elementary and secondary school levels for both the District School Board of Niagara and Niagara Catholic District School Board, Regional Council passed the motion calling on the Province and its Ministries to incorporate the Smart Growth planning principles when making decisions that ultimately impact the community's sustainability and viability (Niagara This Week, 2012). In fact, 
councilors stressed that all school boards under the jurisdiction of the Ontario Ministry of Education should "be required to incorporate Smart Growth principles in its Accommodation Review process to ensure its decisions reflect the future needs of a community based on Smart Growth principles, sustainability and socio-economic responsibilities (Macoomb, 2012).

Niagara's Regional Council also approved the recommendations of the report but the school board has pointed out that unless changes are made to provincial policy, Steering Committee staff have no jurisdiction over school boards.

\subsection{Conclusions}

This case study outlines exactly the issues highlighted with inconsistent provincial and local land use policies. It is highly recommended that this resolution be used as the blueprint for change at the Provincial level (Andres, 2013). The study also effectively illustrates a positive example of change at the local level. Although it has not been successfully implemented to date, the suggestion to create a task force comprised of representatives of school boards, municipalities, and neighbourhoods to address decisions regarding surplus schools introduces the need for a paradigm shift that recognizes the multitude of planning issues associated with these decisions (Smarter Niagara Steering Committee, 2011). The following section will explore these planning issues and outline the factors that should be examined as part of this relationship. The role of municipal planners will also be highlighted. 


\subsection{ANALYSIS}

\subsection{Introduction}

As evidenced by the findings above, there is a clear argument for legislative changes that better align education and urban planning policy objectives. Where the literature provides justification for a role for urban planners in the process, the policy review and the Niagara Region case study summarize the current gaps in the institutional framework to allow municipalities and school boards to work together. In restructuring the policy framework then, new policies would effectively incite the formal participation of urban planners in the school closure decision-making process. As such, building off the conclusions of the Niagara Region case study, this section explores what this collaborative relationship would look like and what important factors could be more closely examined through joint collaboration between municipalities and school boards. The analysis will be structured through two overarching themes that consider:

i. the role of a joint partnership between municipalities and school boards in the overall evaluation of surplus school sites

ii. how these relationships could be used to strengthen the Accommodation Review public consultation process once schools have been identified for closure.

\subsubsection{Schools as social infrastructure}

In order to successfully justify the role for a formal relationship between municipalities and school boards, and consequently, a role for municipal planners in the decision-making process, schools need to be reframed as more than just a place where education occurs. Public schools must be viewed as essential pieces of public infrastructure - both physical and social. The fact that schools represent a considerable inventory of land and physical building stock within cities needs to play a stronger role in how decisions are being made surrounding their future 
(Vincent, 2006). In fact, although a concept that is strongly agreed upon in the school closure literature, in practice schools are rarely thought of as a public good (Kearns, 2009). The reality is, schools offer more than just education for young children between the hours of nine and three, five days a week, ten months a year; schools are an important community benefit that each of its members has access to. Whether it be the buildings themselves or the land upon which they stand, all children have the right to be included in public education and every adult in a community has both a right and a responsibility to be involved in the education of all children (Canadian Teachers' Federation, 2013). School buildings and equipment support community activities, serve as important meeting places for communities, and are major contributors to social cohesion, health, well being, and sense of place (Kearns et al., 2009; Witten et al., 2003; Irwin \& Seasons, 2012). Moving forward then, defining schools as a public benefit needs to become the foundation for a more collaborative and creative decision-making process regarding surplus school space, Inevitably then, recommendations will take the position that this reframing of the definition of public schools become common practice to all stakeholders, including provincial Ministries and local school boards.

\subsection{Role for Municipal Planners - Surplus School Decision-Making}

The purpose of this section is to address what the role of a formally legislated partnership / Task Force between municipalities and school boards should be in the overall evaluation of surplus school sites. This evaluation will consider how a more collaborative relationship at the local level could be used to first and foremost, come up with alternatives to school closures, and subsequently if a school is slated for closure, identify the full cost of these closures. Most importantly, this section will be written from the planning perspective, and will therefore focus more closely on the role of the school in the community. It will also specifically outline the role for municipal planners. Central to this analysis will be the need to keep in mind the following 
question: How can the public continue to benefit from the physical, social, and recreational resource that a school site provides?

\subsubsection{Alternatives to School Closures}

In reference to the case study above, one of the most important benefits of having a formal partnership between municipalities and school boards would be to collectively consider alternatives to closing surplus school sites. There is an ebb and flow to school enrolment, which is what complicates the decision to close one. Once a school is closed because it is in a period of low enrolment, it is lost to the community forever, even when there is an upswing in enrolment projected for the future (Andres, 2013). Most pivotal then, would be to come up with alternatives to closures that would allow schools to provide some or all of their intended uses, while continuing to contribute to overall neighbourhood vitality. Important early in the conversation surrounding surplus school sites would therefore be to identify opportunities for either joint-use of school facilities or alternate uses for these buildings that would allow them to continue to provide public benefits.

\section{Joint Use of School Buildings}

Joint use partnerships can take many forms, but in general can be described as established on-going facilities sharing between a public school board and one other entity (Vincent, 2010). A few examples of these facility sharing initiatives include: expanded outdoor recreational opportunities such as playgrounds, sports fields, and hard court surfaces; expanded indoor recreational opportunities; shared library services; expanded student or community social services; space being used for public private meetings, events or activities; and finally, administrative uses or tenant type arrangements. Though each of these joint use partnerships is encouraged, and should be closely considered in the process of making decisions about surplus schools, the last of these opportunities is the one that should be most closely examined. 
To many elected leaders, public officials, and community members, jointly using public school infrastructure that is paid for by taxpayers makes intuitive sense (Vincent, 2010). Additionally, urban planners and community developers, particularly those in the 'smart growth' movement have long advocated for joint use schools (Fuller et al, 2009). Not only does joint-use of school buildings preserve the community benefits that a school offers, but maintaining schools in built-up neighbourhoods rather than closing them and building them elsewhere helps reduce the multitude of impacts associated with suburban sprawl. Unique to the idea of partnership is that, unlike the options surrounding adaptive re-use of these facilities that will be discussed later in the paper, is that schools can continue to be used as their intended use.

Similar to other education issues; however, within the current policy framework, building these joint-use initiatives into plans and policies at the local level is perceived as a complex and uncertain task (Vincent, 2010). In fact, it is extremely rare for a locality to have an institutional framework in place that allows the required entities to work together in the ways necessary to realize effective joint use (Filardo et al; 2010; Vincent, 2010). In other words, without legislation in place to encourage collaboration between school boards, municipalities, and other public or private entities, the important notion of joint-use of school buildings tends to be the exception, rather than the rule. The result is a missed opportunity to deliberately leverage joint use of schools and other public facilities.

By contrast, the idea of a formal partnership in which public entities are required to work together, positions school boards and municipalities to mutually benefit from these relationships. As Vincent (2010) articulates, a shared vision amongst stakeholders creates a "culture of sharing" that is often missing among staff. In fact, instances of mandated and voluntary collaboration between municipalities and local school boards have produced fruitful and promising interaction and end-results. For example, through his research, Andres (2013) identified a positive example of a smaller urban school in the core of the City of Hamilton that was originally slated for closure, but through a creative use of assets and resources, the 
building was instead partially leased to a private organization. The result of this seemingly simple decision is that Hamilton still has an inner city elementary school near its urban core neighbourhoods.

This notion of identifying temporary tenants for part of a school space is perhaps the most important benefit that could arise from partnerships between municipalities and school boards. Through collectively identifying either private or public institutions that could benefit from sharing these spaces, not only can schools continue to operate as their intended use, but they can also continue to provide recreational and social benefits to the surrounding community. As such, when municipalities are facing decreases in enrolment that are resulting in increasing numbers of surplus spaces in schools, it is critical that a study be done to consider which, if any, of these buildings exhibit the highest potential for joint-use community partnerships. By identifying these buildings, though some consolidation may still occur, school sites that would have otherwise been slated for closure, may continue to remain in public ownership, and as such, continue to perform community benefits.

\section{Alternate Use of Buildings}

Another interesting opportunity for surplus school sites is their ability to perform an alternate use. In cases where joint use partnerships are not possible, efforts could be made to convert the building to something other than its intended use. A concept known as adaptive re-use, schools can be modified or refurbished to accommodate re-use by either a public or private entity that has subsequently purchased the building from the school board after a decision has been made to close it to students. As such, surplus school sites can become a new public resource in which a host of programs and activities can take place. It also offers suitable possibilities for private sector development (Sooley, 2012). 
In the current policy framework, although there are positive examples of the adaptive re-use of many school buildings in Ontario, challenges exist in two broad policy areas. The first of these areas is the lack of political will in requiring municipalities and school boards to work together in an effort to make more creative decisions about surplus school sites. The fact that these two entities are not collaborating with each other reduces the possibility that municipalities will purchase surplus school sites. The second important issue here is that Ontario's policy for the disposal of surplus school sites does not adequately promote the re-use of these spaces as public entities even though municipalities have promoted the re-use of school sites in their Official Plan policies (Rasanu, 2012).

When considering how to incorporate these alternate use opportunities in the surplus school decision-making process, a role for school boards and municipalities to play is to coordinate decisions about efforts to focus on the reuse of these sites. Not only would these initiatives allow schools to continue to provide public benefits to the surrounding community, they would also result in the preservation of a precious piece of shared heritage. Finally, finding alternate uses for surplus school sties would also be considered a win for city-builders in addressing a development challenge in an innovative way (Toronto Artscape, 2013).

In her research, Sooley (2012) identified a number of factors that influence the viability of surplus schools sites for conversion. These factors include demographic and household compositions in the surrounding neighbourhood, new patterns of housing, as well as recent development trends in the area. For example, new patterns of housing demand that emerged in the 1990s resulted in household buyers seeking accommodation closer to the workplace (Sohmer and Lang, 1999). Downtown living has grown in popularity and increased in residential values, which has had an effect on the reuse of school sites. Older school buildings are often also located closer to city centres and transit use (Langston et al., 2008; Sooley, 2012). In addition to being centrally located in a neighbourhood, school buildings are designed for large occupancies. Finally, an important factor to consider that was not included in the Sooley (2012) 
study is the range and quality of community services and facilities in the surrounding area. If a community is lacking in community services, the range of opportunities for surplus school sites significantly increases.

Because of their size and interior layout, schools present excellent opportunities to be reused as public amenities. For example, schools can be re-purposed as community centers or senior centers. Their high ceilings, large hallways, and large gymnasium, library, and cafeteria spaces make these buildings optimal for physical activity and large public meeting spaces. Precedents also exist where these structures have been re-used as private senior housing units (Bridges, 2000). Although public uses for these buildings are encouraged from a community building perspective, the preservation of the large quantities of open space, even when the building itself is private, can continue to benefit the surrounding community (Kennedy, 2010). Finding creative solutions that preserve the environmental, health, and community benefits that these often significant parcels of parkland provide should be at the forefront of decisions involving adaptive re-use of schools.

Finally, the repurposing of schools for the purposes of arts and culture is another consideration worth pursuing. In Toronto, Artscape Youngplace serves as an example of the vast potential that repurposed schools represent. After sitting vacant for more than a decade, the century-old former Shaw Street School underwent a \$17 million transformation to become a new community cultural hub that is open to the public. The reinvigoration of this 75,000 square foot site took many years and involved hundreds of stakeholders in the process, but the end result is a facility designed to meet the community's needs and provide sustainable space for the arts, culture and creativity in Toronto's West End (Toronto Artscape, 2013).

Municipal planners can add valuable input to the conversation surrounding the adaptive reuse of surplus schools. Through evaluating the feasibility of a school as a candidate for adaptive re-use by a private or public entity, planners can determine which school sites would provide the best opportunity for re-use. By reviewing Official Plan policies, Secondary Plans, Parks and 
Open space policies and plans, policies and plans pertaining to community services and facilities, planners can identify different development opportunities for specific sites. Through identifying these opportunities for a multitude of sites under consideration for Accommodation Review, decisions concerning which schools ultimately will be identified for closure can be more easily tailored to those which present the best opportunity for continued public benefit. Also relevant here would be a review of the relevant Zoning By Law to determine what uses are permitted in these areas. Though these uses would vary based on local context, permitted uses in most Ontario municipalities include a place of worship, a community center, a museum, a nursing home, a library etc. (Sooley, 2012). Finally, the planner's analysis would also require an evaluation into what the technical process might be in amending these documents should the building's original use be altered. Douglas (2006) identified a number of possible combinations for changing a building's use, but noted that the configuration to residential and non-residential single uses is more popular than mixed-use conversions because they require less rigorous technical requirements (Sooley, 2012).

\section{$\underline{\text { In Summary }}$}

A formal relationship between school boards and municipalities creates an opportunity to identify the joint use and alternate-use capabilities of multiple surplus school sites before they are officially identified for closure. As Vincent's (2010) research illustrates, successfully expanding the uses of public school facilities requires a system of supports established through formalized, multiagency partnerships that restructure governmental relationships. If provincial policy can successfully accomplish this, joint use or alternate-use partnerships can be used to salvage surplus school spaces. In many of these cases, schools can continue to function as their intended use, but in all cases municipalities can continue to benefit from the intangible health and recreation benefits that these buildings provide. 


\subsubsection{The Full Costs of School Closures}

As illustrated by the literature review, the current definition of 'cost' in the domain of school closures appears to be the largest detriment to collaborative and all-encompassing decisionmaking. The cumulative affects of poor Provincial policies and a lack of comprehensive analysis at the local level have resulted in an incomplete picture of education and the role of a school in the greater community (Andres, 2013). School Boards continue to make decisions to close schools on the grounds of efficiency, declining enrolment, and limited program budgets. Whether it be because of a lack of will on the behalf of the school board, or the crippling affects of an outdated funding formula, the result remains the same: School Boards are making executive decisions about school closures without apparent consideration for the impact on the neighbourhoods left behind, or the possible rebound in student populations (Smarter Niagara Steering Committee, 2011). As a result, they are only looking at one side of the equation.

While factors like demographics, operating expenses, and facility financing are important, the fact that these figures are easily quantifiable has meant that social elements and neighbourhood dynamics have taken a back seat in the process. In reality, neighbourhood schools play multiple roles, not only in providing facilities for teaching and learning, but in offering resources to help meet the social, recreational, and health needs of the community.

As such, although these aspects are unquantifiable in the traditional sense, both the growing body of literature on the subject, as well as the building tension between school boards and municipalities exemplified by the Niagara Region case study provide evidence for a new mixed methods approach to evaluating the full cost of school closures.

The most important justification for involving municipal planners in the Accommodation Review process is therefore their ability to improve the school valuation process. In fact, their addition to the process would actually move it closer to the initial provincial guidelines, where two of the four criteria for consideration speak to the value of the school in maintaining the community, and value of the school's importance to the local economy (Irwin, 2012). Their 
inherent knowledge of provincial and local land use policies afford them the opportunity to advocate for the big-picture role that schools play in community building. Through including planners in the decision-making process, Accommodation Reviews could be re-structured to ensure that school closings are conducive with broader community plans (People for Education, 2012). The following sections will outline what factors are currently missing in the conversation involving the 'full cost' of school closures. The evaluation will be broken up into two parts: Intangibles and Urban Community Objectives.

\section{Intangibles}

Schools are key indicators of community vitality and sustainability. They influence where families choose to live, property values and tax revenues, and the pace and location of residential and commercial development (Vincent, 2006). Schools also provide health benefits by acting as recreational facilities, as well as through fostering active transportation for the many neighbourhood students that walk to school each day. Many communities rely on schools to house health clinics, day care centres, after-school social programs, and adult-education (Lytton, 2011). The purpose of this section is to outline the intangible benefits that schools provide. Although not an exhaustive list, these attributes of a school have been highlighted as deserving recognition throughout the entirety of the school closure decision-making process. In addition to being key criteria in analyzing a school's value to the community and to the economy, these factors should be identified as part of the Accommodation Review public consultation process in an effort to increase the level of transparency in the process.

\section{Recreation Facilities}

In addition to being instrumental in efforts to increase physical activity (Lytton, 2011), schools are important components of a community's park space. Though not always identified as such in municipal Official Plans, the parkland that is associated with schools is an invaluable asset to the community that surrounds them. If a school is sold, along with it goes a convenient place to 
gather for community events, soccer games, or fundraisers. As such, this important open-space attribute of a school is something that should be carefully considered when a decision is being made to close, and subsequently sell a surplus school site.

\section{Health Benefits}

The ability of students to live in walking distance from their schools can play an important role in the level of physical activity children are experiencing. When children live further away from a school, there is less of an opportunity for them to stay after hours to participate in recreational or organized physical activity. For example, studies have indicated that schools located outside a neighbourhood reduce the extra-curricular activity of students, as well as the active involvement of parents (Lytton, 2011). Additionally, students no longer have the option of walking to school. Interesting to note here is the inverse relationship between the average distance walked to school and childhood obesity (Lytton, 2011).

\section{After School Programs}

There are many ways in which social capital is built through the presence of a school, even outside of classroom time (Basu, 2004). Closely related to a school's health benefits above, are the many after school programming initiatives that these schools deliver. Although functions that a school provides, things like adult learning programs and daycare programs are not accounted for in the provincial funding formula, and therefore receive little consideration in the school closure decision-making process. Largely dependent on neighbourhood demographics, the importance of these programs to the direct community is something that needs to be quantified by municipal planners before a final decision is made to close a school.

\section{Environmental Impact}

The environmental impact of closing a school is not insignificant. Rather than being populated with students walking to school, neighbourhood streets become filled with vehicles adding to 
greenhouse gases on their way to a school outside of the neighbourhood. In a climate where environmental assessments have become an important component of many development decisions, the environmental impacts of more vehicles on the road, however minimal, should not be ignored (Smarter Niagara Steering Committee, 2010).

\section{Traffic Impact}

Also related to the bussing/driving of students to other schools is the impact that these vehicles have on traffic patterns within cities. Particularly in areas of the city that are already experiencing congestion (most downtowns and older suburban regions), the additional vehicles and buses in the area can significantly impact traffic flow in neighbourhoods that, because of the existence of the school, have not had to deal with these issues.

\section{Schools as a Public Meeting Space}

Creating an inventory of community facilities in proximity to a school is another important initiative that should be taken when decisions are being made to close them. This is especially true in small or rural locations where schools are among the few public facilities that can provide meeting spaces or serve as recreation centres (Basu, 2004). In areas where schools are performing these important community benefits, decisions to close them should be discouraged from a municipal planning and a community services perspective. Inherent here is the necessity to consider how joint-use partnerships can be developed between public entities that may already be sharing the space.

\section{Neighbourhood Attractability}

Although potentially only a perceived benefit of the presence of a school in a neighbourhood, neighbourhoods are more attractive to current and prospective homebuyers when there is a presence of a school (People for Education, 2009). Imperative for community development then, is that when Official Plans and other municipal planning documents are directing growth and 
development to specific areas, these neighbourhoods remain attractive and contain the necessary public community facilities to support this growth.

\section{Compact Development Initiatives}

Although already mentioned above, smart growth initiatives must be considered in the school closure decision-making process. Aligning revitalization and (re)-development initiatives with education facilities is pivotal. Additionally, new schools tend to take up a larger amount of land than the schools that are being replaced, thus reducing the density potential for the neighbourhood (Smarter Niagara Steering Committee, 2010).

\section{Urban Community Objectives}

Another role for municipal planners in the overall decision of what to do with surplus school properties would be to consider their importance to the objectives of the Official Plan. Returning to the Niagara Case Study for example, this evaluation would focus on the Objectives of the Urban Community policies (Niagara Region, 2011). Perhaps falling under a different name, but nevertheless a common theme in all Official Plans, these objectives are intended to form the underlying motivations for all community building initiatives. Their important role in creating these documents means that planners are well positioned to assess how the presence of an individual school building is contributing to these community-planning goals. Given that an important part of any Accommodation Review requires the value of a school to the community to be demonstrated, through developing even simple evaluation criteria to measure these factors, planners can create a preliminary analysis of the importance of a school to high-level community building policies outlined municipal Official Plans.

Using the Niagara Region as an example of how this process might work, the planner would be tasked with assessing the importance of a given school based to the following Official Plan Urban Community policy objectives: 


\begin{tabular}{|c|c|}
\hline $\begin{array}{l}\text { Policy Objectives } \\
\text { (Niagara Region, 2011) }\end{array}$ & Evaluation Requirement for Municipal Planners \\
\hline $\begin{array}{l}\text { Promote and facilitate the } \\
\text { revitalization and } \\
\text { redevelopment of downtowns }\end{array}$ & $\begin{array}{l}\text { Particularly with recent policy directive for increased intensification } \\
\text { in urban downtown areas (Ontario, 2006), it is critical that the long- } \\
\text { range planning for downtown areas be clearly understood when } \\
\text { schools in these areas are slated for closure. The perceived } \\
\text { importance of schools in attracting young families to an urban area } \\
\text { is not something that can be overlooked. Planners can study } \\
\text { growth projections and long-range planning goals for these areas } \\
\text { and assess the impact that the loss of both the school and its } \\
\text { surrounding land will have on the (re)-development of these areas. }\end{array}$ \\
\hline $\begin{array}{l}\text { Promote the preservation and } \\
\text { enhancement of cultural } \\
\text { heritage resources in } \\
\text { residential areas }\end{array}$ & $\begin{array}{l}\text { Particularly in older neighbourhoods, schools hold intrinsic heritage } \\
\text { value. Even when they have not been designated as heritage sites, } \\
\text { the unique architectural attributes of these structures are things that } \\
\text { many communities want to preserve. Though a building's historical } \\
\text { significance is difficult to quantify, efforts should be made wherever } \\
\text { possible to prioritize these buildings for joint-use or re-use. For } \\
\text { communities experiencing the threat of school closure, finding } \\
\text { alternate uses for these often-impressive structures appeases } \\
\text { communities not ready to part with these buildings (Bridges, 2000). } \\
\text { Generally, re-using these spaces also means the community saves } \\
\text { money on the development of community facilities. }\end{array}$ \\
\hline $\begin{array}{l}\text { Provide for active } \\
\text { transportation within } \\
\text { neighbourhoods with } \\
\text { connections to adjacent } \\
\text { residential and commercial } \\
\text { areas and parks }\end{array}$ & $\begin{array}{l}\text { Studies have shown that once a neighbourhood school is closed or } \\
\text { demolished, formerly walk-able neighbourhoods lose their glue } \\
\text { (Smarter Niagara Steering Committee, 2011). The ability for } \\
\text { students to be able to walk vs. being driven or bussed to school } \\
\text { should be at the forefront of discussions to close them. For } \\
\text { example, there are policy precedents that place a strong emphasis } \\
\text { on protecting these important health benefits. A new consultation } \\
\text { approach taken by the Scottish Parliament involving an } \\
\text { assessment on the health factors associated with walking to school } \\
\text { has resulted in legislation that defines the closure of rural Scottish } \\
\text { schools as decisions of last resort (Hargreaves, 2007). }\end{array}$ \\
\hline
\end{tabular}




\begin{tabular}{|c|c|}
\hline $\begin{array}{l}\text { Contribute to a sense of } \\
\text { safety within the public realm }\end{array}$ & $\begin{array}{l}\text { Not only can schools foster active transportation, but this important } \\
\text { aspect of students walking to and from school each day, often with } \\
\text { their parents, can significantly increase the sense of safety in the } \\
\text { public realm. Particularly in areas where public safety is of high } \\
\text { concern, the presence of a school can reduce the threat of crime } \\
\text { simply by acting as a high traffic area (Andres, 2013). }\end{array}$ \\
\hline $\begin{array}{l}\text { Balance the need for private } \\
\text { and public place }\end{array}$ & $\begin{array}{l}\text { Schools provide unique opportunities to function as either public or } \\
\text { private spaces. For example, during regular daytime hours, schools } \\
\text { provide important educational benefits to their students. After the } \\
\text { school day is over; however, these buildings have the potential to } \\
\text { be rented out to private organizations or sports teams, as well as to } \\
\text { function as public spaces for community events. These important } \\
\text { features of a school, along with their opportunity for joint-use } \\
\text { partnerships make them unique pieces of community infrastructure. }\end{array}$ \\
\hline $\begin{array}{l}\text { Encourages a variety of } \\
\text { connections based on } \\
\text { transportation mode between } \\
\text { land uses. }\end{array}$ & $\begin{array}{l}\text { A school's accessibility is important not only for students, but also } \\
\text { for parents and community members. A school that is well } \\
\text { positioned in terms of proximity to transportation corridors, as well } \\
\text { as other commercial or institutional land uses is important to the } \\
\text { community in many ways. Connections from these buildings to } \\
\text { other land-uses facilitate the ability for both parents and other } \\
\text { community members to access these buildings, even if they do not } \\
\text { own a vehicle. Additionally, when surplus school spaces are } \\
\text { identified, buildings that offer a range of connections between } \\
\text { multiple land uses are more appealing and appropriate for joint-use } \\
\text { and adaptive re-use alternatives. }\end{array}$ \\
\hline
\end{tabular}

Table 1 - The objectives of municipal planners in satisfying a municipality's Urban Community Objectives

\section{In Summary}

Joint partnerships between municipalities and school boards can create a framework for a municipal planning analysis of the full costs of school closures. The importance of schools to overarching development criteria is something that should be given careful evaluation prior to 
decisions being made about the future of any surplus school site. Through analyzing the intangible benefits that schools provide to their immediate communities, a more complete picture of the costs of closing these facilities can be presented.

\subsection{Role for Municipal Planners - Accommodation Review Consultation Process}

While the evaluation of school closure decisions from a land use and urban planning perspective is certainly important, planners can also perform an important role in re-shaping the Accommodation Review consultation process. As evident from the literature, the current Accommodation Review process is widely criticized by professionals and academics in both education and planning. Though many of the criticisms presented by those in the field of education stem from issues surrounding an inequitable funding formula, arguments from those on the planning side are grounded in issues surrounding transparency, accountability, and the greater coordination of Provincial policy. While Accommodation Review Guidelines preach a strong foundation in participatory and community based decision-making principles, these principles do not appear to be effectively implemented at the local level.

Planners, once again, are in a unique position to improve these important areas. Particularly in recent decades, planners have moved away from the traditional rationalcomprehensive method of decision-making towards a more collaborative and consensus building strategy (Innes, 1996). Likewise, as suggested above, the multi-disciplinary nature of the field of urban planning provides for a more comprehensive analysis of all the costs of school closures, and not simply those listed by the Province of Ontario on their School Valuation checklist (Irwin \& Seasons, 2012). Not only could planners play important roles as key stakeholders lobbying for growth-related and community building principles, but lessons learned from planning theory could be incorporated into the process in order to move toward the intended transparent and participatory nature of the Accommodation Review. The following 
section will discuss how both the theory and practice of urban planning can be used to foster a more comprehensive and participatory Accommodation Review public consultation process. Although once again acknowledging the importance of high-level policies in shaping the current framework of Accommodation Review, this section is simply intended to consider how planners could contribute to the process should they be given a formal role.

\subsubsection{Alternative Decision-Making Models}

By structuring the decision-making process through a framework grounded in efficiency, the aspect of accountability for local school boards is threatened. As mentioned before, this view only places value on certain attributes of a school. In the realm of school closures; however, where these decisions can only be described as 'wicked problems' (Rittel \& Webber, 1973), this model of decision-making paints an incomplete picture of all the factors involved. By definition, wicked problems are those that are difficult to solve because of incomplete, contradictory, and changing requirements that are often difficult to recognize or quantify and where the answer to one component of the problem often leads to more problems. The complexity of these problems is therefore completely undermined when solutions are being determined by only one of many relevant stakeholders.

Moreover, the perception from the public that Accommodation Reviews are "over before they start" (Fredua-Kwarteng, 2005) and applied simply to satisfy the requirements of a provincially mandated decision-making process, means that decisions are being made in a tokenistic fashion (Andres, 2013). Tokenism, described as seeking input out of obligation only, effectively nullifies the feeling of empowerment that community members experience when engaging in fully participatory decision-making processes. In essence, there is the need for a more inclusive and collaborative decision-making process wherein the community is afforded the opportunity to provide constructive suggestions that will be meaningfully considered by those ultimately crafting final recommendations. 
The field of urban planning, or more specifically the input of urban planners, has the capability to provide a unique aspect to the Accommodation Review stakeholder consultation process. In both theory and practice, the complex nature of planning issues has required planners to move away from the rational-comprehensive model of decision-making, towards one of increased collaboration and consensus building (Irwin \& Seasons, 2012). In planning literature, for example, there is an emerging trend that questions the efficacy of policy design that is removed from community, and advocates for a more meaningful public participatory approach in policy development practice (Campbell, 2010; Irwin \& Seasons, 2012). This type of planning is classified as collaborative planning which, in conjunction with full-cost accounting of economic, environmental, and social consequences, addresses the fundamental challenge of planning: a rapidly changing society (Allmendinger, 2009; Andres, 2013).

It should be noted that planners have not achieved a perfected policy system, yet a strong argument can be made that school boards and education professionals could benefit from the expertise of planners and the ideology of collaborative policy creation and implementation (Andres, 2013). Not only would this process increase the level of meaningful participation of all stakeholders, but it would also create the foundation for a more accountable and transparent decision-making process. Although demographic trends and financial constraints do not disappear through a more collaborative process, the inclusion of multiple stakeholders in the process creates an opportunity for more creativity in the decision-making environment (Andres, 2013).

\subsection{Conclusions}

In summary, increasing the level of participation of municipal planners through a formal relationship between municipalities and school boards can create the following opportunities:

1. Determine alternatives to school closures by identifying the potential for both joint-use partnerships and alternate-use capabilities of a piece of school infrastructure. If these 
buildings can be used in a way that allows them to remain in public ownership, the recreational and social benefits that these buildings provide can continue to play a role in overall neighbourhood vitality.

2. Identify the full costs of a school closure to the surrounding neighbourhood. Through identifying the intangible benefits that schools provide, particularly in the context of overall urban community objectives, a more complete picture of the impact of their closure can be painted.

3. Improve how Accommodation Reviews are conducted by introducing more collaborative decision-making models. 


\subsection{RECOMMENDATIONS}

As was illustrated through the course of this paper, the current process of making decisions about the future of surplus schools is in need of fundamental changes to both its provincial and local policy context. Currently the decisions to close local schools leaves community residents outraged, municipal governments powerless, and school boards exhausted and frustrated (Andres, 2013). Although a topic that continues to have more questions than answers, the following recommendations and suggestions for future research hope to synthesize the key issues in the current surplus school policy and decision-making framework. Keeping in mind that the issue is being viewed through an urban planning lens, recommendations have been identified that could improve the manner in which decisions are made about the future of surplus schools.

\subsection{Provincial Policy}

1. Align Ministry of Education policies with those from the Ministry of Infrastructure and the Ministry of Municipal Affaires and Housing.

Both municipalities and school boards operate in compliance with provincial government legislation, policies, and guidelines. To date; however, Provincial Ministries appear to have made little effort in coordinating their policy objectives. Most pivotal to improving the school closure decision-making process in the future is the need for the Ministry of Education to design its Accommodation Review policies with explicit regard for the social, economic, and environmental impacts of school closures on communities. Not only this, in the interest of assisting municipal efforts to plan and achieve sustainable forms of urban development, its policies must be structured in a way that they compliment the policies and guidelines of the Ministries of Infrastructure and Municipal Affaires and Housing. Policies must therefore address smart growth development principles and relevant urban community building objectives that will ultimately impact the community's sustainability and viability. For example, States where the 
Department of Education advocates for formal relationships between these organizations have found greater success in educating local Trustees and Boards about Smart Growth policies and with saving several schools (People for Education, 2009).

\section{Update Accommodation Review Guidelines to provide a clear framework for} collaboration with municipal governments and planning authorities in order to extend the reach and parameters of their school closure studies.

Upper tier governments must make room for creativity and flexibility in Accommodation Reviews by adapting to the benefits of facility sharing, after-hours use, and other municipal partnerships (People for Education, 2009). The current Accommodation Review process places too much value on the educational benefits of a school and almost no value on the other community benefits that these buildings provide (Irwin, 2012). By including municipal governments and their associated planning staff in the decision-making process, two important outcomes can begin to take shape. The first involves using the expertise of municipal planners to conduct planning reviews of the 'intangible' benefits that these surplus school sites provide to both the surrounding community as well as the long-range planning goals of the municipality as a whole. Identifying the appropriate criteria and measures to ascertain these benefits would be a significant contribution to the decision-making surrounding school closures. Their expertise on the provision of public benefits therefore means that planning departments and municipalities must engage in the Accommodation Review process in addition to lobbying the Province for policy changes (Andres, 2013).

The second important benefit that the field of urban planning can add to the Accommodation Review process would involve developing alternate decision-making models wherein a clear framework of collaboration and consensus building take the place of current tokenistic models of community consultation. The Province's public participation guidelines seem dated and unresponsive to community and stakeholder groups who expect a greater 
degree of transparency, accountability and meaningful decision-making role (Fredua-Kwarteng, 2005).

3. Update Ontario's Regulation 444/98 - Disposition of Surplus Real Property to afford municipalities a better opportunity to purchase surplus school sites.

The importance of keeping schools in public ownership is critical to maintaining the many benefits that these buildings provide in terms of social and recreational infrastructure. Although other education facilities have, and should continue to have, the first chance at taking over these facilities, municipalities are in the most appropriate secondary position to ensure that schools continue to provide these intended neighbourhood benefits. In order to afford municipalities the opportunity to conduct a full community services and community-planning study prior to these sites being demolished or sold to a re-developer, the time frame for municipalities to make offers on surplus school sites should be extended. This simple policy change would allow all alternatives to school closure to be considered. Most important here are considerations for alternate uses for institutional buildings that remain in good condition, but because of low student enrolment, have outlived their original intended use. Finally, private redevelopment should be considered but only after public buildings have been proven unnecessary or infeasible (Rasanu, 2012). With keeping the land ownership public, surplus school sites and their surrounding land should continue to provide community benefits.

\section{Amend Accommodation Review Legislation to ensure that school closures and the location of new schools are subject to appeal to the Ontario Municipal Board by the municipality.}

This recommendation is contingent upon the recommendations above being put into action such that the closure of schools are recognized as a land-use planning issue. Should this occur, changes would be required to the Ontario Municipal Board Act that would allow these decisions 
to be subject to appeal by all those involved in the process. By allowing these decisions to be appealed, it would be possible to ensure that all necessary steps have been taken and would also afford all stakeholders the right to challenge these decisions.

\subsection{Local Policy}

1. Require the creation of a partnership between municipalities and school boards when surplus school spaces are identified but before individual buildings are slated for Accommodation Review.

Municipalities, through their Official Plans and Accommodation Review should be required to work together in finding alternatives to school closures. Although Official Plans presently recognize the need for municipalities and school boards to work together when determining the future of a surplus school site, the language of these policies is often suggestive rather than authoritative (Smarter Niagara Steering Committee, 2011). Official Plan policies pertaining to surplus school sites should therefore be updated to ensure that the uses of public school spaces are expanded to support a wide variety of positive outcomes. These outcomes include, but are not limited to, establishing schools as centers of community, increasing opportunities for physical activities, more efficiently using public funds, and broadening services and amenities for students, families, and communities (Sooley, 2012). Finally, incorporating schoolyards into the park planning process would allow them to be recognized as well-used community parks and force the city to consider their importance when a school site is sold.

On their part, Accommodation Review policies should require the participation of municipalities in the School Valuation process. This is especially important when considering the value of a school to the community. Introducing a more fully developed assessment of the "intangible" benefits that schools provide would better inform and enhance the decision process.

Incentives might also be useful in fostering working relationships between school boards and local municipalities to plan school infrastructure as part of larg-scale development plans 
(Vincent, 2010). For example, some US states have recommended and/or encouraged school boards to employ joint use strategies where possible. Ontario; however, should take this objective one step further and develop legislation and/or policies that facilitate and encourage the sharing of school facilities for community use through appropriate policies, procedures, and financial incentives.

\subsection{Municipal Planning Initiatives}

1. Municipal planning departments should, in collaboration with local school boards, be obligated to prepare a planning report to present the intangible benefits of a school to urban neighbourhoods.

Acknowledging that changes to provincial and local policies take time, at a minimum, municipal governments (City Councils) should be requiring municipalities, school boards, and their associated planning departments to work together in identifying optimal surplus school locations for joint-use partnerships. When surplus space is identified, a planning report should underscore the following:

i) Joint or alternate uses for the building. Potential interim uses of the school building, a portion of the building, and/or of the school land site should be investigated based on potential and prospective needs of both the school and the community, along with consideration of the extent of renovation required to accommodate this interim use (Smarter Niagara Steering Committee, 2011). When multiple sites are identified, the study should determine which of these locations present the highest opportunity for joint-use between school boards and municipalities. Important to this assessment would be a community facilities evaluation in the immediate area to see if services can be shared. Although consolidation might still occur, some or all, of the original intended uses of a school site have a better opportunity of being preserved.

ii) The intangible benefits of a school. These important added dimensions should include factors related to "smart growth" such as the walkability and diversity of neighbourhoods, the role of the school as a central rallying point for a neighbourhood, the health benefits to children of walking to school and playing in the 
school yard after school hours, the potential natural quality of the playground space attached to the school, and the likely savings to municipalities of using surplus space in schools for alternative purposes such as recreation, expanded education and training opportunities, fitness and health centres, and child and teen drop-in programs (Smarter Niagara Steering Committee, 2011). This is especially important in high-density neighbourhoods where children have limited access to outdoor play areas, restricted access to nature and natural surroundings, and even less access to safe play areas outside the immediate home environment (People for Education, 2009).

iii) The importance of the school in satisfying Official Plan Objectives (i.e. Niagara Region's Urban Community Objectives). 


\subsection{BIBLIOGRAPHY}

Andres, S (2013). Connecting School Closures and Community Planning. University of Waterloo Thesis. Retrieved September 21, 2013 from: http://uwspace.uwaterloo.ca/bitstream/10012/7458 /1/Andres_Spencer.pdf

Basu, R. 2004. A Flyvbergian perspective on public elementary school closures in Toronto: A question of "rationality" or "power"? Environment and Planning C 22: 423-451.

Basu, R. 2004a. The rationalization of neoliberalism in Ontario's public education system, 19952000. Geoforum 35: 621-634.

Basu, R. 2007. Negotiating acts of citizenship in an era of neoliberal reform: The game of school closures. International Journal of Urban and Regional Research 31(1): 109-127.

Bridges (2000). Back to School: Communities Ace Adaptive Re-use Test. Federal Reserve Bank of St. Louis. Retrieved March 5, 2014 from: https://www.stlouisfed.org/publications/br /articles/?id=707

Bushrod, G. M. (1999). School closure and its impact on community. Ann Arbor, MI: University of Michigan.

Button, Jessica (2009). The Re-use of Surplus School Sites in Ottawa, Ontario: An examination of Community Interests and Public Participation in the Acquisition, Planning, and Conversion of Surplus School Sites. A thesis submitted to Queen's University. Retrieved March 4 from: http://www.queensu.ca/surp/sites/webpublish.queensu.ca.surpwww/files/files/Reports/Button_R eport_ExecSummary.pdf

Campbell, D. (2010). Democratic norms to deliberative forms: Managing tools and tradeoffs in community-based civic engagement. Public Administration and Management, 5, 305-342. Canada. Constitution Act of 1867. Retrieved from http://laws.justice.gc.ca/eng/Const/

Canadian Teachers' Federation, (2013). Reframing Public Education as a Public Good. Retrieved March 4 from: http://www.ctf-fce.ca/Research-Library/Educationpublicgood.pdf

City of Toronto (2010). Official Plan - 2010 Consolidation. Retrieved February 23, 2014 from: http://www1.toronto.ca/static_files/CityPlanning/PDF/chapters1_5_dec2010.pdf

District School Board of Niagara (2013). Accommodation Reviews Facility Planning. Retrieved: February 17, 2014: http://www.dsbn.edu.on.ca/uploadedFiles/Accommodation_Reviews /Facility\%20Planning\%20Report\%20-\%20June\%202013.pdf

Doern, B., \& Prince, M. (1989). The political administration of school closures: Administrators, trustees and community groups. Canadian Public Policy, XV, 450-469.

Filardo, M., Vincent, J.M., Allen, M., and Franklin, J. (2010). Joint Use of Public Schools: A Framework for a New Social Contract. Washington, DC: 21st Century School Fund.

Filion, E and T. Bunting. 2010. Transition in the city. In Canadian cities in transition, eds. T. Bunting, R Filion and R. Walker. 4th edition. Toronto: Oxford, 39-52. 
Fredua-Kwateng, E. (2005). School closures in Ontario: Who has the final say? Canadian Journal of Educational Administration and Policy, 46, 2-26.

Fuller, B., Vincent, J. M., McKoy, D., \& Bierbaum, A. H. (2009). Smart schools, smart growth: Investing in education facilities and stronger communities (Working Paper 2009-03). Berkeley, CA: University of California, Berkeley, Institute of Urban and Regional Development.

Hampton, G. (2009). Narrative policy analysis and the integration of public involvement in decision-making. Policy Science, 42, 227-242.

Hargreaves, A. (2007). Consultation on Scottish school closures. Educational Journal, 118, 47.

Innes, J (1996). Planning Through Consensus Building: A New View of the Comprehensive Planning Ideal. American Planning Association. Journal of the American Planning Association 62. $4: 460$.

Irwin, B. and Seasons, M. (2012). School closure decision-making processes: problems and prospects. Canadian Journal of Urban Research, 21(2), 1-23

Irwin, W. 2012. Public school closures in Ontario: A case of conflicting values? Unpublished dissertation. Faculty of Education, University of Western Ontario, London, ON.

Kearns, R., Lewis, N., McCreanor, T., \& Witten, K. (2009). "The status quo is not an option": Community impacts of school closures in South Taranaki, New Zealand. Journal of Rural Studies, 25, 131-140.

Keevers, L., Treleaven, L., \& Sykes, C. (2008). Partnership and participation: Contradictions and tensions in the social policy space. Australian Journal of Social Issues, 43, 459-479.

Kennedy, Mike (2010). Adaptive re-use enables schools and universities to repurpose existing buildings and extend the life of outdate facilities. American School and University.

Kitchen, H (2002). Municipal Revenue and Expenditure Issues in Canada. Canadian Tax Payer No. 107, Canadian Tax Foundation, Toronto

Lytton, Michael (2011). Have all the costs of closing a school been considered? CELE Exchange 2011(8). Retrieved March 2, 2014 from: http://www.oecd.org/edu/innovation education/centreforeffectivelearningenvironmentscele/48358265.pdf

Mackenzie (2007). Missing the Mark. How Ontario's education funding formula is shortchanging students. Canadian Centre for Policy Alternatives. Retrieved January 16, 2014 from: http://www.policyalternatives.ca

Macoomb, S (2012). District of Niagara to review policies. Retrieved February 13, 2014 from: http://www.brockpress.com/2012/01/district-school-board-of-niagara-to-review-policies/

Maryland Public School Construction Program. (N.d.) Aging School Program. Retrieved October 30, 2013 at: http://www.pscp.state.md.us/. 
Niagara this week (2012). School Review must follow Smart Growth: council

Retrieved February 11, 2014: http://www.niagarathisweek.com/ news-story/3265383-schoolreview-must-follow-smart-growth-council/

Niagara Region (2009). Sustainable Community Policies: Places to Grow /2005 Provincial Policy Statement Conformity and Niagara 2031 Amendment. Retrieved February 14, 2013: http://www.niagararegion.ca/government/initiatives/2031/pdf/RPPA2-2009.pdf

Niagara Region (2011). Niagara Region Official Plan. http://www.niagararegion.ca/living/icp/pdf/ policy/physical-economic-background-2011-Policy-Plan.pdf

Ontario. Ministry of Education. (1997a). Bill 160, Education Quality Improvement Act, 1997.

Retrieved November 5, 2013 from http://www.ontla.on.ca/web/committeeproceedings

/committee_transcripts_details.do?locale=en\&Date=1997-103\&ParlCommID=39\&BillID=\&

Business=Bill+160C+Education+Quality+Improvement+Act+1997\&DocumentID=18919.

Ontario. Ministry of Education. (1997b). Bill 104, Fewer School Boards Act, 1997. Retrieved November 5, 2013 from http://www.ontla.on.ca/web/committeeproceedings/ committee_transcripts_details.do ?locale $=$ en\&Date=1997-03-\&ParlCommID $=54 \& B i l l I D=\&$ Business=Bill+104+Fewer+School+ Boards+Act1997\& DocumentID=18827.

Ontario. Ministry of Education. (2006). Pupil accommodation review guidelines. Retrieved January 20, 2014 from http://www.edu.gov.on.ca/ eng/policyfunding/reviewGuide.pdf

Ontario. Ministry of Education. (2009). Revised Public Accommodation Review Guidelines. Retrieved January 20, 2014 from http://faab.edu.gov.on.ca/Memos/B2009/B_07.pdf

Ontario. Ministry of Infrastructure. (2005). Places to Grow Act. Retrieved February $20^{\text {th }}$ from: http://www.e-laws.gov.on.ca/html/statutes/english/elaws_statutes_05p13_e.htm

Ontario. (2006). Places to Grow - Growth Plan for the Greater Golden Horseshoe.

Retrieved on February 27, 2012 from https://www.placestogrow.ca/index.php

Pascopela, A. (2004). The rural road. District Administration, 40(10), 71-76.

People for Education. (2009). School closings and declining enrolment in Ontario.

Toronto, ON: People for Education. Retrieved January 5, 2014 from:

http://www.peopleforeducation.ca/wp-content/uploads/2011/09/School-closings-and-decliningenrolment-in-Ontario-People-for-Education-20091.pdf

People for Education, (2012). Declining Enrolment/School Closings. Retrieved March 1, 2014 from: http://www.peopleforeducation.ca/wp-content/uploads/2012/05/declining-enrolment-earlyrelease-2012.pdf

Rasanu, S (2012). The Acquisition and Redevelopment of Surplus Schools in Toronto, Ontario: An Assessment of the City of Toronto's School Lands Property Acquisition Policy. Queen's University Thesis. Retrieved February 25, 2014 from:

http://qspace.library.queensu.ca/bitstream /1974/7351/1/Master's\%20 Report\%20Final\%20 \%20August $\% 202012 \% 20$ (Simona\%20Rasanu)

Rittel, H. and Webber, M. (1973). Dilemmas in a general theory of planning. Policy Sciences, 4, 155-169 
Seasons, M. (2013). School Closures: A Planning Perspective. A Presentation prepared for the CIP-INFUSE Conference (July 8, 2013). Waterloo Environment. Retrieved February 20, 2014 from: http://www.infuse2013.ca/media/Session\%2028\%20-\%20SeasonsINFUSE.pdf

Smarter Niagara Steering Committee (2011). District School Board of Niagara - Smarter Schools for a Smarter Niagara. Retrieved February 11, 2014 from: http://www.dsbn.edu.on.ca/ uploadedFiles/Accommodation_Reviews/Current_ARCS/Niagara_on_the_Lake_Elementary_Sc hools/NOTL\%20Committee\%20Minutes\%200ct\%2030-13\%20Website\%20Town-Res.pdf

Sooley, L (2012). "An Examination Of The Benefits And Constraints Of Adaptive Reuse Of Surplus School Sites" (2012). Theses and dissertations. Paper 1765.

Statistics Canada (2012). Population and Demography. Retrieved February 24, 2013 from: http://www5.statcan.gc.ca/subject-sujet/result-resultat?pid=3867\&id=-

3867\&lang=eng\&type $=$ CENSUSTBL $\&$ pageNum $=1 \&$ more $=0$

Toronto Artscape, (2013). Repurposing Schools as Cultural Spaces. Retrieved March 4, 2013 from: http://torontoartscape.org/sites/default/files/News\%20Release_Repurposing\%20 Schools\%20as\%20Cultural\%20Spaces_FINAL.pdf

Vincent, J (2006). Public schools as public infrastructure: Roles for planning researchers. Journal of Planning Education and Research 25: 433-437. Retrieved January 30 ${ }^{\text {th }}, 2014$ from: http://citiesandschools.berkeley.edu/reports/Vincent_2006_JPER_Public_School_Infra.pdf

Vincent, J (2010). Partnerships for Joint Use - Expanding the Use of Public School Infrastructure to Benefit Students and Communities. Retrieved March 8 ${ }^{\text {th }}, 2014$ from: http://citiesandschools.berkeley.edu/reports/Partnerships_JU_Aug2010.pdf

Witten, K., McCreanor, T., Kearns, R., and Ramasubramanian, L (2001). The impacts of a school closure on neighbourhood cohesion: narratives from Invercargill, New Zealand. Health \& Place 7:307-317.

Witten, K., Kearns,R., Lewis, N., Coster, H., and McCreanor, T (2003). Educational restructuring from a community viewpoint: A case study of school closure from Invercargill, New Zealand. Environment and Planning C 21: 203-223 